\title{
A cross-cultural analysis of the motivation factors and profitability of online wine tastings during Covid-19 pandemic
}

Online wine tastings during Covid-19 pandemic

\author{
Gergely Szolnoki \\ Geisenheim University, Geisenheim, Germany \\ Moritz Nikolaus Lueke \\ Institute of Masters of Wine, London, UK \\ Maximilian Tafel and Marvin Blass \\ Geisenheim University, Geisenheim, Germany, and \\ Niklas Ridoff and Calle Nilsson \\ Winetourism.com, Stockholm, Sweden
}

Received 30 April 2021

Revised 19 July 2021

6 August 2021

Accepted 25 August 2021

\begin{abstract}
Purpose - The pioneers of online wine tastings have set a new standard and introduced an innovative tool that combines various goals: contacting existing and recruiting new customers, entertaining participants and boosting sales. Within the framework of the study, the authors addressed questions such as the reasons for offering online wine tasting, profitability and the basic characteristics and future perspectives of this new interactive online tool.

Design/methodology/approach - A mixed-methods research was conducted using a sequential exploratory design to analyse online wine tastings during Covid-19 pandemic. First, 40 in-depth interviews in Germany were conducted and, based on these results, a global online survey was undertaken with 1,423 wineries from more than 40 countries.

Findings - The survey results clearly show the effect of Covid-19 on the growing tendency to employ online wine tastings. This tool is about more than just providing entertainment for wine lovers in that it also has a tangible business aspect.

Practical implications - Based on these results, the authors assume that online wine tastings will continue to be offered after the Covid-19 crisis.

Originality/value - This paper offers a situation analysis of the first 10 months of the Covid-19 pandemic in the field of online wine tastings worldwide. The authors conducted a quantitative online survey that built on a qualitative pre-study. Given the fact that no academic paper has been published on the topic, this paper provides first insights on a global scale.
\end{abstract}

Keywords Online wine tasting, Cellar door, Mixed-method research, Covid-19 pandemic

Paper type Research paper

(C) Gergely Szolnoki, Moritz Nikolaus Lueke, Maximilian Tafel, Marvin Blass, Niklas Ridoff and Calle Nilsson. Published by Emerald Publishing Limited. This article is published under the Creative Commons Attribution (CC BY 4.0) licence. Anyone may reproduce, distribute, translate and create derivative works of this article (for both commercial and non-commercial purposes), subject to full attribution to the original publication and authors. The full terms of this licence may be seen at http:// creativecommons.org/licences/by/4.0/legalcode

The qualitative part of this study was conducted as part of a Master of Wine examination research paper submitted by one of the co-authors. The authors thank the Institute of Master of Wine for their support and permission to publish the results. In addition, the authors want to thank all wine associations and regional offices that helped us to distribute the link to the questionnaire and all wineries participated in the survey.

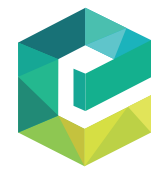

British Food Journal Vol. 123 No. 13, 2021 pp. 599-617 Emerald Publishing Limited 0007-070X DOI 10.1108/BFJ-04-2021-0438 
BFJ

123,13

600

\section{Introduction}

The Covid-19 pandemic has had severe negative worldwide effects, tipping the global economy into the worst recession since World War II (World Bank, 2020). In many countries, restaurants were forced to close, airlines were grounded, tourism stopped. Overall, it was estimated that international tourism would have dropped by $60-80 \%$ in 2020 (OECD, 2020). Almost all countries were facing a significant recession in 2020, often with sharply increased unemployment rates (BBC, 2020). The cancellation of international wine fairs, vintage presentations, wine festivals has led to revenue drops in many markets and for various products, including wine (Saini et al., 2020).

As Bruwer (2002) stated, wine tastings and cellar door sales are important economic factors for wineries; moreover, they are very beneficial for brand loyalty (Bruwer et al., 2013). Social distancing and other regulations imposed in many countries due to the Covid-19 pandemic have significantly reduced wineries' ability to deliver these experiences and generate sales via this channel, especially during the lockdowns. The wine industry's answer to these negative effects of the Covid-19 pandemic was online wine tastings (OWTs), and have become one of the most visible tools used by wineries since the beginning of the crisis. OWT is a particular form of interactive wine tasting or evaluation. With the help of a pre-ordered wine tasting package, the participants can experience the event via the Internet using recording techniques (chat, forums, FAQ, etc.) in sound and vision and participate passively but also actively (WeinPlus, 2021). Another form of OWTs are tastings combined with annual meetings, vintage or wine procurement presentations and negotiations in $\mathrm{B} 2 \mathrm{~B}$ field between producers and retailers, exporters or importers.

OWTs can help overcome the problems resulting from social distancing rules, as they use digital platforms that permit video conferencing or live streaming through channels such as Zoom, Facebook or Instagram. In these OWTs, participants can interact with the winemaker and taste the same wines at the same time regardless of their location (Der Spiegel, 2020).

Since OWT is a brand-new online tool that has been able to help to overcome losses in the crisis, the practical importance is of great interest in the wine industry. From the scientific point of view, we are facing here a research field, which has appeared at the beginning of the pandemic and revolutionised the traditional way of a wine touristic activity. Given that no academic paper has been published on the topic so far, this pioneering study provides first insights for scientific purposes.

Therefore, this paper aims to investigate the spread of OTWs worldwide and shed light on the motives, goals, and profitability of these newly created virtual events from the wineries' perspective on a global scale. In addition, as emphasised in several other publications (e.g. Szolnoki et al., 2018 or Ferraris et al., 2020), a cross-cultural analysis helps to understand significant differences in the usage of OWTs between seven various countries. Thus, from the scientific perspective, this paper should contribute to the missing literature on strategies wineries applied during the lockdown. As part of the practical implications, the results also help to understand the strengths and weaknesses of OWTs and provide best practice solutions for the wine industry.

In regard to the paper's structure, the literature overview builds the theoretical background of the study. In the next chapter, the methodological approach is described, followed by the results. The chapter Discussion, including practical implications, limitations and further research concludes the paper.

\section{Literature review}

The wine industry, especially in larger production or consumption countries, is of great economic importance that should not be underestimated. According to Szolnoki's (2018) findings, in Germany for example, $12 \%$ of the annual wine sales volume is purchased through cellar doors and wine tastings therein, representing a value share of $22 \%$ with a total turnover 
of $€ 1.44$ billion. As described in the paper by Bresciani et al. (2016), the wine sector offers great opportunities not only for wine makers, but all the relating industry branches such as bars, restaurants, e-commerce companies etc. According to their findings, wine companies in Italy have managed to increase their economic performance after the world consumption crisis in 2007-2008. Santos et al. (2021) have already predicted the innovation of the ecosystem as one of the main drivers in recent times in wine tourism. Thus, the new generations of wine tourists will be faced with digital and/or hybrid wine events and the increased usage of digital channels and platforms. This finding shows the importance of OWTs during and after the crisis in 2020/21.

\subsection{Wine tastings and adoption of innovation}

In order to understand the economic challenge posed to wineries by the banning of face-toface wine tastings, it is necessary to look at the importance of these traditional tools. Bruwer et al. (2013) describe winery cellar door as the hub of the visitor's wine tourism experience " ... presenting winery owners with the opportunity to provide an authentic and memorable experience ...”. McMillan (2019) reported that direct-to-consumer sales represent $65 \%$ of an average winery's revenue in California driven by tasting rooms and clubs.

To take advantage of the positive impacts offered by cellar doors and the tastings therein, wineries need to create a positive experience for their visitors. Factors that are important for memorable and enjoyable wine tasting experiences are winery attributes, themes and activities, education and novelty (Saayman and van der Merwe, 2015), as well as knowledgeable staff, the variety of wines available for tasting and the tasting room's appearance (Janney, 2012). Furthermore, tasting room experiences should be provided on a personal level to establish an emotional connection between the visitor, product and winery staff (Fountain et al., 2008).

Positive experiences at cellar door wine tastings have a significant beneficial influence on purchase intentions and the value and quantity of the products purchased (Shapiro and Gomez, 2014; Gill et al., 2007). These positive experiences increase clients' wine knowledge and involvement, both of which are factors that correlate strongly with higher wine consumption (Szolnoki, 2018; Ho and Gallagher, 2005). Underlining the importance of professional clients visiting wineries is that salespersons with better product knowledge demonstrate better performance results (Siagian et al., 2020).

Tasting rooms act as a form of experiential marketing for wineries. There is a strong correlation between enjoyable, memorable cellar door experiences and brand loyalty, the likelihood of repeat purchases, greater growth in off-premise retail sales and the promotion of the wine/brand to others (Cuellar et al., 2015; Bruwer et al., 2013; Nowak and Newton, 2006). In New Zealand, for example, $46 \%$ of winery visitors made a post-visit purchase $6-8$ months later, $59 \%$ of visitors made a positive word-of-mouth recommendation regarding the wine and 65\% recommended visiting the winery (Mitchell and Hall, 2004). This shows that besides actual visits and purchases at a winery, many cellar door visitors can become "brand promoters" and share their positive impressions with potential new clients. This is an important consideration given that $37 \%$ of potential visitors rely on word-of-mouth recommendations when deciding which winery to visit (Bruwer and Reilly, 2006) and that the role of friends in influencing wine consumption is becoming more significant (Agnoli et al., 2013). Smyczek et al. (2020) also emphasised the importance of a positive tastig room experience for the success of direct sales.

Furthermore, in locations other than wineries, wine tasting can positively influence sales. Scanner data analysed by Lockshin and Knott (2009) showed that sales of wines tasted in shops increased by $400 \%$ on the day of tasting, with no difference between customers attending a tasting with the intention to purchase and those just stopping by.
Online wine tastings during Covid-19 pandemic 
BFJ

123,13

602

While more traffic at the cellar door is beneficial for direct sales (Cuellar and Eyler, 2012), visitors in small groups tend to spend more money on wine than those in large groups (Velikova and Dodd, 2009). According to Vrontis et al. (2020), culinary tourism that also includes wine tourism, is a relevant factor, which - when communicated by using online technology - strengthens the perception and the brand image of the winery. This underlines the importance of the new technology and new online platform in times of restrictions.

Numbers of studies have already investigated the adoption of new online communication platforms. Szolnoki et al. (2014), Galati et al. (2018), Szolnoki et al. (2018), as well as Galati et al. (2019) stated in their studies that wineries around the world underwent in the last decade a significant change and adopted new online technologies.

\subsection{Wine consumer trends in the Covid-19 era}

The Covid-19 pandemic has influenced and will continue to change general consumer behaviour (Fabius et al., 2020), resulting, for example, in a significant increase in social media usage and online shopping (UNTCAD, 2020). In a study with 886 US consumers, Thach and Velikova (2020) found that wine consumers partly increased their spending and consumption and adopted new motivations for wine consumption during the lockdown. US wine consumers who consume wine at least once a week increased their online wine purchases by $50 \%$. In a recent study from Italy, Alaimo et al. (2020) found that due to the Covid-19 pandemic, a rethinking in consumers' behaviour happened. Consumers became more open to using online platforms, even when it comes to purchasing food.

In Germany, online channels have experienced a significant rise in usage amongst wine consumers, with $21 \%$ reporting in June 2020 that they had bought wine online more often (Wine Intelligence, 2020a). Furthermore, consumers spent more money on wine and consumed it more frequently on non-food occasions (Wine Intelligence, 2020b) because gastronomy outlets were closed. By the end of the first quarter of 2020, German wineries reported a decrease in on-trade sales of $55 \%$ and a drop of 35\% in exports. Even stronger adverse effects for the second quarter were forecasted by Wines of Germany (2020). On the other hand, the gastronomy sector reported a $40.5 \%$ decrease in sales in the period from March to August (Destatis, 2020). Hence, many wineries with a high share of sales through this channel were severely affected in a negative way.

\subsection{Online wine tastings}

Due to the very recent appearance of OWTs, no scientific papers have been published on this subject yet. OWTs have existed for quite some time but were rarely used. One of the first public OWTs was conducted in 2001 in Germany at Geisenheim University, entitled "Wine event, Riesling worldwide" (Lönarz, 2001). Fischer (2009) pointed out that OWTs can offer cost- and time-saving effects due to reduced travel, the benefits of having a direct communication channel with clients and positive effects on brand awareness thanks to increased exposure on social media and blogs. Despite these important insights, OWTs did not become important in terms of being used by a significant number of wineries in any country, nor did they achieve widespread public awareness in the wine industry.

This changed with the arrival of the Covid-19 pandemic and the resulting restrictions. Many companies in different sectors of the wine industry quickly started to offer OWTs for business-to-business (B2B) and business-to-consumer (B2C) clients (Harpers, 2020; Meininger's Sommelier, 2020). In April 2020, the famous international wine critic James Suckling (2020) also quickly adopted OWTs, offering "Zoom tastings" with winery owners, tasting and discussing wines on his website from mid-April 2020 onwards.

As shown by a preliminary study with participating wineries mainly from Spain and Italy, $32 \%$ of wineries have developed OWTs as a strategy to compensate for wine tourism losses (Garibaldi, 2020). German wineries were fortunate that two key national publications, Der 
Spiegel and Frankfurter Allgemeine Zeitung, published articles about OWTs in Germany, followed by frequent positive coverage in various media. Moreover, the platform "cheerswith.de" was established, offering wineries a free service for OWTs and actively asking them to participate (Meininger's Weinwelt, 2020).

Kirschenmann (2020) reported on different OWT formats. One of these, "personalised virtual tastings", has an often-limited number of guests and uses platforms such as Zoom, Webex or GoToMeeting. Such OWTs offer a more intimate setting with the possibility of direct interaction. A second format uses "Livestreams", which are broadcast via, for example, YouTube Live, Facebook or Instagram Live. They are less scripted and offer an extensive reach to potential clients. A third option is "happy hours", when wineries go online and interact with their clients on an unscripted, casual level, essentially making this format a virtual get-together with a glass of wine. Such online happy hours were also reported in the UK (Gilbert, 2020). Urban (2020) and Kirschenmann (2020) looked at practical advice for OWTs, suggesting that, when preparing and conducting them, particular attention should be paid to technical issues, advertising and creating interesting tasting packages as well as the timing and content of the event. OWTs may have a seasonal element as wineries have reported decreased demand for OWTs during the summer (Krupp, 2020); this seems only natural following the lockdown situation. Wen and Leung (2021) investigated the effect of virtual reality (VR) wine tours and found that VR, especially in combination with a wine tasting, has a higher influence than watching traditional video clips.

Due to the lack of travel possibilities, wineries and other organisations started to use OWTs for educational purposes, such as staff training or virtual business meetings (Riley, 2020), substituting personal settings. As Carmer et al. (2020) stated in their study, changing wine courses of sensory perceptions training form face-to-face to fully online, many challenges are emerging. However, as the best practice results show, suitable soulutions coukd be found. Shifting to virtual settings can positively impact companies, not only by increasing employee job satisfaction due to saving time and increasing work flexibility but also by saving travel costs and contributing to the reduction of greenhouse emissions (Abrahamsson Lindeblad, 2012; Anderson and Anderson, 2009).

\section{Research methodology}

\subsection{Objectives}

To our knowledge, no comparative study has investigated OWTs on a global scale. Therefore, this research aims to develop new knowledge about OWTs, which may help wineries replicate the positive effects offered by winery/cellar door visits and wine tastings through their online offerings. The study could also have implications for other challenges facing cellar door operations, such as wildfires, which have also adversely affected wine tourism (Veseth, 2017). Besides, the academic contribution, primarily due to the lack of published results on a global scale, should not be underestimated.

Building on previous literature that analysed the tasting room experience and given the fact that no scientific publication exists so far in this field, this study addresses the following research questions:

$R Q 1$. How big is the share of wineries offering OWTs?

$R Q 2$. What are the main reasons a winery offers OWTs?

RQ3. What are the basic characteristics (number of events, length, number of participants, platform and target groups) of OWTs?

$R Q 4$. How profitable are OWTs?

RQ5. What does the future of OWTs look like?
Online wine tastings during Covid-19 pandemic

603 
BFJ

123,13

604
These research questions were examined in a cross-national context to understand the cultural differences between seven various countries. In addition, size-of-the-winery-based differences were analysed too.

Since there are no preliminary findings on OWTs, mixed methods research was conducted using a sequential exploratory design. According to Creswell et al. (2003), this research design can be undertaken when researchers conduct a primarily quantitative study, but it needs to begin with initial qualitative data collection in order to identify or narrow the focus of possible variables. Therefore, first we conducted qualitative in-depth interviews with wineries that provided first insights into OWTs. These insights were then used to develop a quantitative online questionnaire. The online survey helped to verify the findings and to analyse differences within the sub-groups formed.

\subsection{Qualitative approach}

Semi-structured, in-depth interviews using open questions were conducted between July and October 2020 with winery owners in Germany. A total of 30 wineries were interviewed using a question catalogue, which focused on the reasons behind and the objectives, perceived benefits and challenges, as well as the financial implications, of OWTs. These wineries were selected from a list provided by the German Wine Institute, which contained 144 wineries offering OWTs. Another ten wineries that did not host OWTs were also interviewed in order to discover why they were against virtual tastings.

After their transcription, the interviews were analysed using content analysis. Content analysis is a technique that organises terms from interview answers into a systematic scheme, enabling other researchers to replicate the data extraction. Grouping answers according to specific characteristics, such as size or wine region, and analysing causal connections constituted the other part of the content analysis (Krippendorff, 2004). To ensure the consistency of the research, the interviews were conducted and analysed by the same native speaker interviewer.

\subsection{Quantitative approach}

In a second step, a structured online survey was conducted in January and February 2021. We took the findings of the exploratory qualitative interviews conducted in the first step and integrated the outcome into the quantitative questionnaire as questions or response categories.

Using winetourism.com's database of 10,000 email addresses of producers worldwide, we collected answers from a total of 1,423 wineries in 42 countries, resulting in a response rate of $14 \%$.

Considering the results of Friedmann and Amoo's (1999) study on rating scales, we used five-point interval scales in the questionnaire to gauge the responses to statements regarding profitability. For the other questions, simple- or multiple-choice answers were used, and the responses to the questions about country and region of origin were recorded by applying open questions.

The data were analysed with SPSS 26.0 (IBM) using mean, frequency and cross-tabulation analysis. To analyse the differences between the sub-groups formed, we, similarly to Mueller et al. (2011), used $\chi^{2}$ with Cramer's V for cases with more than four cells (Field, 2005).

\section{Results and discussion}

\subsection{Qualitative survey}

As already mentioned above, the explorative qualitative survey served the purpose of collecting first insights into OWTs, which were used for the development of a quantitative 
questionnaire. Therefore, in this subchapter, we only list the main topics and the most important answers mentioned by the interview partners.

One of the most important topics, which almost always came up at the very beginning of the interviews, was the reason for using OWTs. Winery managers often used terms such as motivation, goal, aim or motive to describe the main reasons for offering OWTs. The majority of the interviewees agreed that replacing cancelled events, increasing brand awareness and strengthening customer loyalty were their most important goals. Besides, new consumer acquisition and direct sales increases were also mentioned. Wineries that had not hosted OWTs in the past also mentioned reasons for not using OWTs, such as an insufficient number of consumers or a lack of interest on the part of the winery.

As a second discussion point during the interviews, interviewees referred to the profitability of OWTs. Depending on the winery's goal, it was not always the most important factor. Some participants reported no monetary benefits, whereas others were able to generate profits through OWTs.

The interviewees were also asked in detail about the basic characteristics of OWTs. They knew the exact number of OWTs that had already been hosted, their average length and the number of visitors. The online platform used for hosting online tastings and the target group were also mentioned.

Mainly at the end of the interviews, the wineries also touched upon the challenges of OWTs, of which the most important were as follows: technical issues, the shipping of tasting sets, finding participants, selecting the right wines and creating additional content. In addition, participants also shared their future plans in regard to OWTs.

The results of the in-depth interviews provided a good basis for designing a follow-up quantitative online survey. This questionnaire contained 18 questions grouped into the following categories: 1 ) a filter question (when the winery started offering OWTs - before 2020, in 2020, did not offer OWTs); 2) goals to be achieved with OWTs; 3) basic characteristics of OWTs (total number, length, platform and target group of OTWs, number of participants per tasting and technical challenges); 4) profitability; 5) reasons for not hosting OWTs; 6) future activities regarding OWTs; 7) country and region of the winery; and 8) vine-growing surface area. The questionnaire was initially drafted and piloted in German and then backand-forth translated to English. The final version was distributed worldwide in English.

\subsection{Quantitative survey}

To gain first insights into the structure of wineries that participated in the survey, an overview of the data set was generated that divided the respondents by country of origin and the winery size (in hectares). Of the 1,423 participants from 42 different countries, most came from Germany (345), followed by Italy (334), France (223), Spain (112), Portugal (52), Austria (50) and the USA (50). The remaining 257 cases came from 35 other countries. In terms of company size, the data set was well-balanced: $31 \%$ of small wineries with up to 10 hectares, $26 \%$ with between 11 and 20 hectares, $23 \%$ with between 21 and 60 hectares and another $20 \%$ of wineries with more than 60 hectares. When comparing the size and country, it was apparent that Germany and the USA have an above-average share of small wineries, while the highest shares of larger wineries could be found in Spain and Portugal.

4.2.1 Share of wineries conducting online wine tastings. Around one-third of the wineries surveyed (36\%) introduced OWTs during the Covid-19 pandemic. The share of wineries that already hosted OWTs before the pandemic was only $3 \%$. In contrast, over $60 \%$ of respondents did not offer OWTs for various reasons. These results show that OWTs were introduced because of necessity as a consequence of the pandemic. These results are comparable with the findings by Loose and Nelgen (2021), who conducted a survey with 1,092 wineries worldwide and identified that $37 \%$ of them reacted to the changes and restrictions with OWTs.
Online wine tastings during Covid-19 pandemic 
$\mathrm{BFJ}$ 123,13

\section{6}

The cross-cultural patterns differ significantly (Table 1). The wineries in the USA, Germany and Spain offered most of the OWTs. Italy, Portugal and Austria each provided an average of around $30 \%$ of the OWTs; however, France had a low share $(16 \%)$ of the OWTs. When comparing the wineries of different sizes, it becomes obvious that size does matter. The larger the winery, the more OWTs have been organised. However, the results of the survey also show that larger wineries had the highest decreases in terms of winery visitors.

4.2.2 Reasons for offering OWTs. The top reason for offering OWTs was to create marketing value and increase brand awareness $(67 \%)$, which was already identified as playing a key role in previous studies by Gill et al. (2007) and Bruwer et al. (2013) when the tasting room experience was studied. In addition, this result also underlines the findings by Vrontis et al. (2020). Market value and brand was closely followed by replacing cancelled events/winery visits $(65 \%)$ and trying to attract new customers $(64 \%)$. These factors correlate strongly with the adoption of innovativeness described by Szolnoki et al. (2018) and Galati et al. (2019). Besides, wineries also aimed to strengthen the loyalty of their existing customers $(62 \%)$. The importance of the tasting room experience and the development of a long-term relationship between winery and consumers have already been confirmed by Fountain et al. (2008) and Bruwer and Lesschaeve (2012). Interestingly, increasing direct sales was the least mentioned reason for offering OWTs $(56 \%)$. However, it was still mentioned by more than half of the respondents, and the difference, when compared to the other reasons, was less than $12 \%$.

As the results indicate, the reasons for offering OWTs are multifaceted, and all the response options seem to be quite important. This might be due to the fact that OWTs are an unknown tool with very short prehistory. This could indicate that respondents were not sure regarding their expectations and hoped to obtain several advantages from this online activity. When comparing cross-cultural differences (Table 2), we see that the main reasons for German winery operators choosing to introduce OWTs were replacing cancelled events $(76 \%)$ and acquiring new customers $(78 \%)$. Customer loyalty $(70 \%)$ was also frequently mentioned by German participants.

For Spanish wineries, marketing value and brand awareness $(76 \%)$ was the most important reason, while US, German and Portuguese wineries concentrated more on increasing direct sales. We also recognised significant differences when grouping by size: small wineries mainly offered OWTs to acquire new customers and to replace cancelled

Table 1.

Wineries that conducted OWTs or not by country and the size of the winery $(n=1,423)$

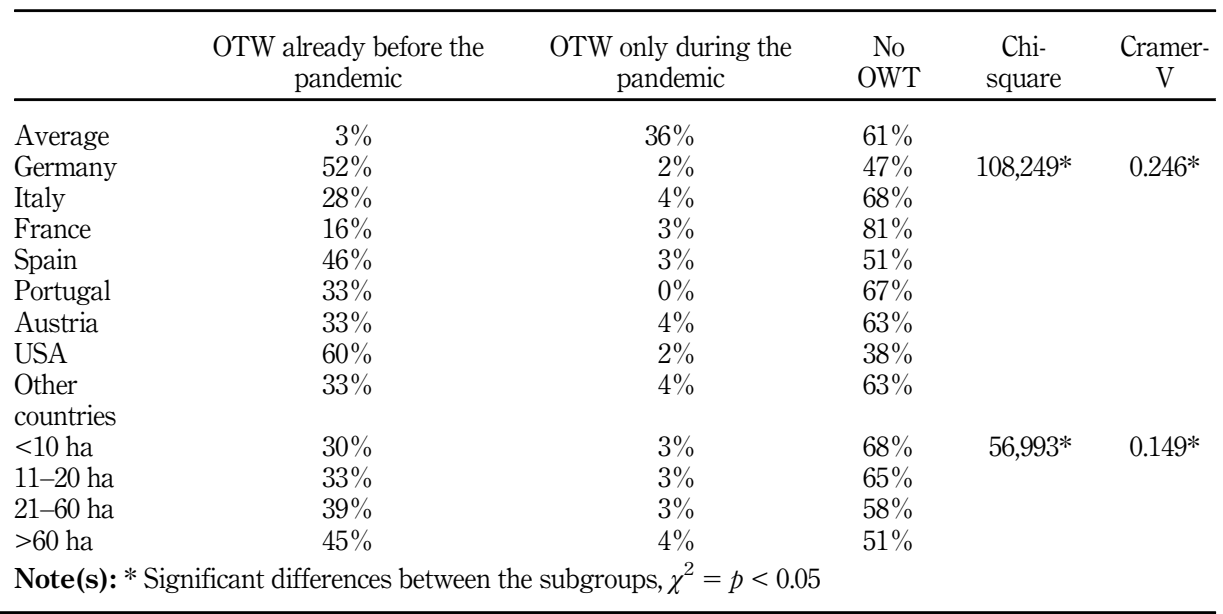




\begin{tabular}{|c|c|c|c|c|c|c|}
\hline & $\begin{array}{c}\text { Marketing value } \\
\text { and brand } \\
\text { awareness }\end{array}$ & $\begin{array}{c}\text { Replace cancelled } \\
\text { events/winery } \\
\text { visits }\end{array}$ & $\begin{array}{c}\text { Acquire new } \\
\text { customers }\end{array}$ & $\begin{array}{c}\text { Strengthen } \\
\text { customer loyalty }\end{array}$ & $\begin{array}{c}\text { Increase } \\
\text { direct sales }\end{array}$ & $\begin{array}{l}\text { tastings during } \\
\text { Covid-19 }\end{array}$ \\
\hline Average & $67 \%$ & $65 \%$ & $64 \%$ & $62 \%$ & $56 \%$ & pal \\
\hline Germany & $59 \%$ & $76 \%$ & $78 \%$ & $70 \%$ & $64 \%$ & \\
\hline Italy & $74 \%$ & $47 \%$ & $59 \%$ & $50 \%$ & $44 \%$ & \\
\hline France & $58 \%$ & $67 \%$ & $58 \%$ & $49 \%$ & $47 \%$ & 607 \\
\hline Spain & $76 \%$ & $60 \%$ & $64 \%$ & $67 \%$ & $45 \%$ & \\
\hline Portugal & $59 \%$ & $65 \%$ & $47 \%$ & $53 \%$ & $65 \%$ & \\
\hline Austria & $72 \%$ & $72 \%$ & $44 \%$ & $72 \%$ & $39 \%$ & \\
\hline USA & $67 \%$ & $67 \%$ & $60 \%$ & $73 \%$ & $73 \%$ & \\
\hline $\begin{array}{l}\text { Other } \\
\text { countries }\end{array}$ & $72 \%$ & $65 \%$ & $51 \%$ & $59 \%$ & $62 \%$ & \\
\hline Chi-square & $46,748 *$ & $86,522^{*}$ & $97,936^{*}$ & $89,413^{*}$ & $82,576^{*}$ & \\
\hline Cramer-V & $0.195^{*}$ & $0.247^{*}$ & $0.262^{*}$ & $0.251 *$ & $0.241 *$ & \\
\hline$<10$ ha & $58 \%$ & $59 \%$ & $68 \%$ & $59 \%$ & $56 \%$ & \\
\hline $11-20$ ha & $63 \%$ & $68 \%$ & $63 \%$ & $57 \%$ & $62 \%$ & \\
\hline $21-60$ ha & $68 \%$ & $65 \%$ & $63 \%$ & $57 \%$ & $66 \%$ & \\
\hline$>60$ ha & $78 \%$ & $69 \%$ & $60 \%$ & $52 \%$ & $64 \%$ & Reasons for offering \\
\hline Chi-square & $38,088^{*}$ & $21,469 *$ & 6,86 & $22,534^{*}$ & 5,891 & $\begin{array}{l}\text { Reasons for offering } \\
\text { online wine tastings by }\end{array}$ \\
\hline Cramer-V & $0.164^{*}$ & $0.123^{*}$ & 0.069 & $0.126^{*}$ & 0.064 & country and the size of \\
\hline \multicolumn{7}{|c|}{ Note(s): $*$ Significant differences between the subgroups, $\chi^{2}=p<0.05$} \\
\hline
\end{tabular}

events, whereas larger wineries aimed more towards increasing marketing value and/or brand awareness $(78 \%)$.

4.2.3 Basic characteristics of OWTs. The basic characteristics were described using the number of OWTs conducted in 2020, the average number of participants and length of the OWTs, the platform used for the tasting and the main target group. Figure 1 summarises the first four dimensions of the characteristics.

According to the results, more than half of the wineries (54\%) hosted up to 5 OWTs, while $35 \%$ conducted between 6 and 20 online sessions. Only a tiny part of the participants organised more than 20 OWTs in the previous year. Of the $54 \%$ wineries with a limited number of OWTs, several wineries only hosted OWTs once or twice, just to try out this new platform.

The number of participants varied greatly from winery to winery. Around three-quarters of the OWTs $(73 \%)$ were held with less than 20 participants. Many OWTs were even hosted with less than 10 participants $(42 \%)$. Only $11 \%$ of such tastings had more than 40 participants. With respect to the cross-cultural differences, we can state that $24 \%$ of the wineries in Germany organised OWTs with more than 41 participants, whereas the shares of those in other countries were much lower. Italy (68\%), France $(63 \%)$ and Spain $(62 \%)$ offered relatively high proportions of OWTs with less than 11 participants. Regarding the time frame, two-thirds of all OWTs (67\%) lasted between 30 and 90 min, $14 \%$ lasted less than $30 \mathrm{~min}$, and the remaining $19 \%$ took longer than $90 \mathrm{~min}$. Of course, the length of a wine tasting depends on a number of factors, e.g. the number of wines tasted, the number of participants and the structure of the tasting. German wineries held, on average, the longest OWTs, with $48 \%$ of tastings lasting longer than 90 min.

When analysing the platforms used for OWTs, the results show that almost two-thirds of the surveyed wineries $(62 \%)$ chose Zoom for conducting their OWTs (Figure 1). Other platforms, such as YouTube, Instagram or Facebook, but also Skype, played a rather subordinate role (each less than $10 \%$ ).

The country-specific results show that in Germany, a quarter of wineries used YouTube; in the USA, a quarter of wineries used Facebook; and in Spain, 22\% used Instagram for their 
BFJ

123,13

608

Figure 1.

Basic characteristics of OWTs $(n=551)$

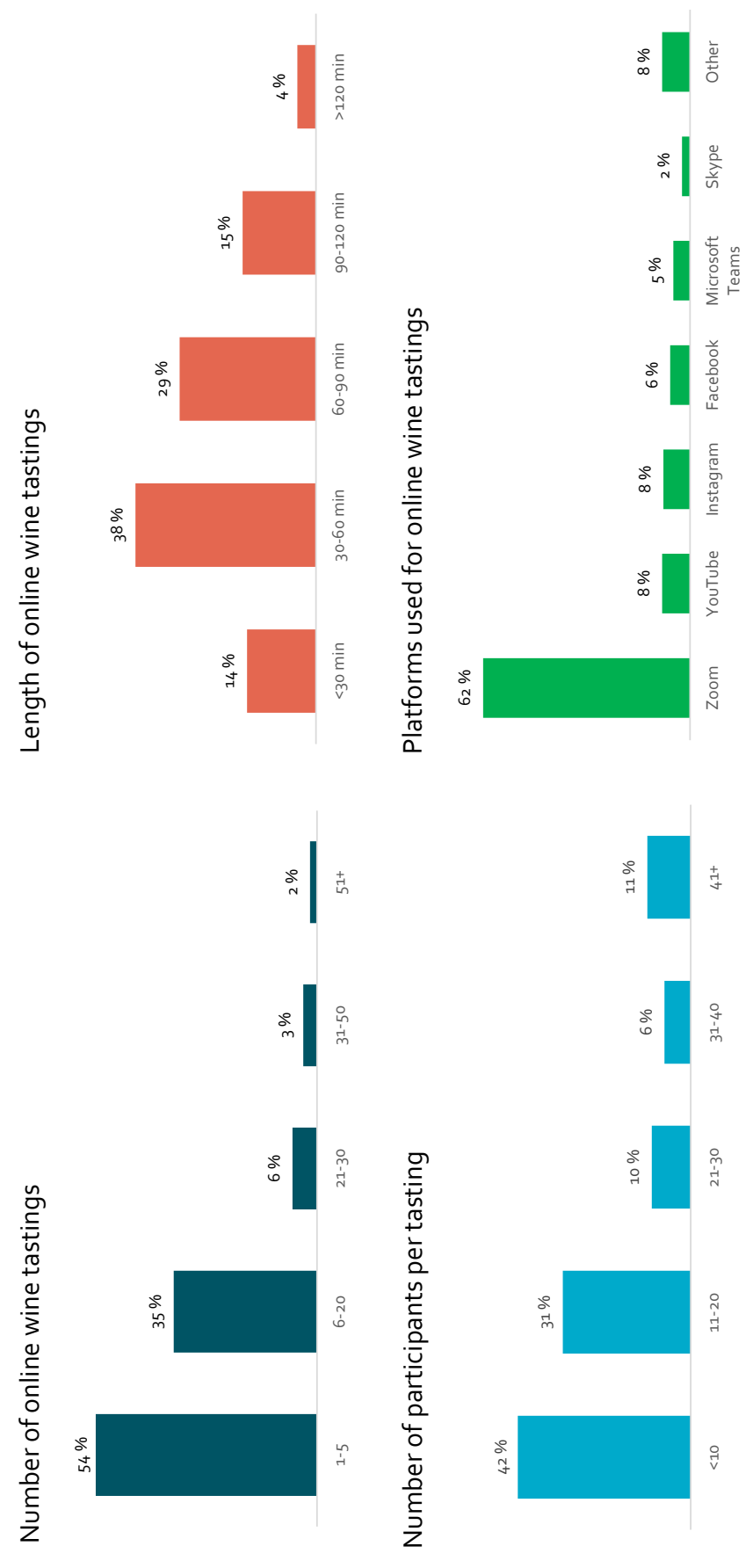


OWTs, breaking the overall hegemony of Zoom. However, Zoom is by far the most used platform and has several obvious advantages. As stated in Serhan's (2020) and Kuntz et al.'s (2020) papers, Zoom is a versatile tool used for private and educational, political, research, business, etc., purposes. This has contributed to it obtaining worldwide publicity. Besides, Zoom is easy to use and enables sharing of visual content without installation and participant accounts (Henry and Shellenbarger, 2020).

One of the main cultural differences appears when comparing the main target groups that OWTs were offered to (Table 3). Every second winery stated that the OWTs were meant to mainly target private clients. Another $29 \%$ were offered to both consumers and business partners, while $20 \%$ of the participants hosted OWTs exclusively for business partners $(20 \%)$. This result is an indicator of the versatility of OWTs, meaning they can be used to replace both private and business events. It seems that, after the most important wine fairs for business purposes were cancelled and/or postponed in 2020 (e.g. ProWein, Vinitaly, Bordeaux Wine Fair), OWTs served the wineries fairly well as B2B platforms, too. In terms of cross-cultural differences, Germany, with a share of $82 \%$ of OWTs for private clients, significantly differed from the other countries. All the other countries, including France $(40 \%)$, Italy (32\%) and Spain (29), had bigger shares of business-oriented OWTs. As for the company size, larger wineries had higher shares of $\mathrm{B} 2 \mathrm{~B}$ online tastings.

4.2.4 Profitability of OWTs. More than half of the wineries that hosted OWTs rated them as profitable or very profitable. Only $6 \%$ of the wineries reported that OWTs had not been profitable, while $38 \%$ reported non-monetary benefits (Table 4). German (71\%) and US $(70 \%)$ wineries achieved the highest profitability. Countries like Austria (72\%), France $(60 \%)$ and Italy $(54 \%)$ have a higher share of wineries that did not achieve monetary benefits from OWTs. However, as discussed in the previous subchapter, these countries focused on B2B-oriented online tastings, which means that tasting sets were probably sent out for free, resulting in no immediate monetary benefits. Interestingly, the size of the winery had no effect on the profitability of OWTs. As Tafel and Szolnoki (2020) stated, wine tourism activities might have a high impact on the profitability of a winery. Therefore, it has been crucial that wineries that offered wine touristic activities before the pandemic develop a strategy that contributes to their profitability. OWTs seem to be an excellent way to counter decreasing sales.

When summarising the success factors of OWTs in terms of profitability, it becomes obvious that the number of OWTs, the number of participants, the length of the tasting and the target group are of central importance (Table 5). The profitable wineries hosted a higher

\begin{tabular}{|c|c|c|c|c|c|}
\hline & $\mathrm{B} 2 \mathrm{C}$ & $\mathrm{B} 2 \mathrm{~B}$ & $\mathrm{~B} 2 \mathrm{C} \& \mathrm{~B} 2 \mathrm{~B}$ & Chi-square & Cramer-V \\
\hline Average & $51 \%$ & $20 \%$ & $29 \%$ & & \\
\hline Germany & $82 \%$ & $5 \%$ & $14 \%$ & $20,741^{*}$ & $0.194^{*}$ \\
\hline Italy & $33 \%$ & $32 \%$ & $36 \%$ & & \\
\hline France & $21 \%$ & $40 \%$ & $40 \%$ & & \\
\hline Spain & $45 \%$ & $29 \%$ & $25 \%$ & & \\
\hline Portugal & $35 \%$ & $24 \%$ & $41 \%$ & & \\
\hline Austria & $22 \%$ & $28 \%$ & $50 \%$ & & \\
\hline USA & $47 \%$ & $20 \%$ & $33 \%$ & & \\
\hline Other countries & $39 \%$ & $21 \%$ & $40 \%$ & & \\
\hline$<10$ ha & $62 \%$ & $16 \%$ & $22 \%$ & $121,027^{*}$ & $0.469 *$ \\
\hline $11-20$ ha & $58 \%$ & $15 \%$ & $27 \%$ & & \\
\hline 21-60 ha & $46 \%$ & $21 \%$ & $33 \%$ & & \\
\hline$>60$ ha & $39 \%$ & $29 \%$ & $33 \%$ & & \\
\hline
\end{tabular}

Note(s): * Significant differences between the subgroups, $\chi^{2}=p<0.05$
Online wine tastings during Covid-19 pandemic

609
Table 3.
Main target group of
OWTs by country and
the size of the
winery $(n=551)$ 


\begin{tabular}{|c|c|c|c|c|c|c|}
\hline \multirow{2}{*}{$\begin{array}{l}\text { BFJ } \\
123,13\end{array}$} & & \multirow[b]{2}{*}{ Unprofitable } & \multirow[b]{2}{*}{ No monetary benefits } & \multirow[b]{2}{*}{ Profitable } & \multirow[b]{2}{*}{ Chi-square } & \multirow[b]{2}{*}{ Cramer-V } \\
\hline & & & & & & \\
\hline \multirow[b]{6}{*}{610} & Average & $6 \%$ & $38 \%$ & \multirow{2}{*}{$\begin{array}{l}56 \% \\
71 \%\end{array}$} & \multirow{4}{*}{$53,850^{*}$} & \multirow{4}{*}{$0.313^{*}$} \\
\hline & \multirow{4}{*}{$\begin{array}{l}\text { Germany } \\
\text { Italy } \\
\text { France } \\
\text { Spain }\end{array}$} & $5 \%$ & $24 \%$ & & & \\
\hline & & $8 \%$ & $54 \%$ & $37 \%$ & & \\
\hline & & $2 \%$ & $60 \%$ & $37 \%$ & & \\
\hline & & $7 \%$ & $40 \%$ & $53 \%$ & \multirow{9}{*}{3,589} & \multirow{9}{*}{0.081} \\
\hline & Portugal & $6 \%$ & $35 \%$ & $59 \%$ & & \\
\hline & Austria & $6 \%$ & $72 \%$ & $22 \%$ & & \\
\hline \multirow{7}{*}{$\begin{array}{l}\text { Table } 4 \text {. } \\
\text { Profitability of OWTs } \\
\text { by country and the size } \\
\text { of the winery }(n=551)\end{array}$} & USA & $3 \%$ & $27 \%$ & $70 \%$ & & \\
\hline & Other countries & $7 \%$ & $33 \%$ & $60 \%$ & & \\
\hline & $<10$ ha & $4 \%$ & $36 \%$ & $60 \%$ & & \\
\hline & $11-20$ ha & $6 \%$ & $36 \%$ & $58 \%$ & & \\
\hline & $21-60$ ha & $7 \%$ & $38 \%$ & $55 \%$ & & \\
\hline & $>60$ ha & $6 \%$ & $43 \%$ & $51 \%$ & & \\
\hline & \multicolumn{6}{|c|}{ Note(s): * Significant differences between the subgroups, $\chi^{2}=p<0.05$} \\
\hline
\end{tabular}

\begin{tabular}{|c|c|c|c|c|c|}
\hline & Unprofitable & No monetary benefits & Profitable & Chi-square & Cramer-V \\
\hline $\begin{array}{l}\text { Number of } \\
1-5 \\
6-20 \\
21-30 \\
31-50 \\
>50\end{array}$ & $\begin{array}{l}7 \% \\
5 \% \\
3 \% \\
6 \% \\
0 \%\end{array}$ & $\begin{array}{l}47 \% \\
30 \% \\
31 \% \\
17 \% \\
11 \%\end{array}$ & $\begin{array}{l}46 \% \\
64 \% \\
66 \% \\
78 \% \\
89 \%\end{array}$ & $25,673^{*}$ & $0.219 *$ \\
\hline $\begin{array}{l}\text { Number of } p \\
<10 \\
11-20 \\
21-30 \\
31-40 \\
>40\end{array}$ & $\begin{array}{l}\text { ipants } \\
8 \% \\
6 \% \\
\\
3 \% \\
3 \%\end{array}$ & $\begin{array}{l}48 \% \\
38 \% \\
23 \% \\
20 \% \\
24 \%\end{array}$ & $\begin{array}{l}44 \% \\
56 \% \\
77 \% \\
77 \% \\
72 \%\end{array}$ & $36,287^{*}$ & $0.258^{*}$ \\
\hline $\begin{array}{l}\text { Length of } O \\
<30 \mathrm{~min} \\
30-60 \mathrm{~min} \\
60-90 \mathrm{~min} \\
90-120 \mathrm{~min} \\
>120 \mathrm{~min}\end{array}$ & $\begin{array}{l}5 \% \\
7 \% \\
5 \% \\
6 \% \\
5 \%\end{array}$ & $\begin{array}{l}54 \% \\
49 \% \\
29 \% \\
19 \% \\
14 \%\end{array}$ & $\begin{array}{l}41 \% \\
44 \% \\
66 \% \\
75 \% \\
81 \%\end{array}$ & $44,367 *$ & $0.287^{*}$ \\
\hline $\begin{array}{l}\text { Target grou } \\
\text { B2C } \\
\text { B2B } \\
\text { B2C \& B2B }\end{array}$ & $\begin{array}{l}6 \% \\
8 \% \\
4 \%\end{array}$ & $\begin{array}{l}29 \% \\
55 \% \\
42 \%\end{array}$ & $\begin{array}{l}65 \% \\
37 \% \\
53 \%\end{array}$ & $27,585^{*}$ & $0.224^{*}$ \\
\hline \multicolumn{6}{|c|}{ Note(s): * Significant differences between the subgroups, $\chi^{2}=p<0.05$} \\
\hline
\end{tabular}

number of OWTs, and $64 \%$ of the wineries that did not make a profit from OWTs hosted them less than six times. More than half of the unprofitable wineries in the sample held OWTs with less than 11 participants. Having a higher number of participants seems to be more profitable.

It is interesting to note that the duration of the OWT also determines its outcome. The profitable wineries organised longer tasting sessions, probably with more wines and more content ( $27 \%$ longer than $90 \mathrm{~min}$ ). In contrast, $57 \%$ of the unprofitable wineries held OWTs that lasted for less than $60 \mathrm{~min}$ on average. 
Regarding the target group, wineries achieved profits with OWTs by mainly hosting B2C or mixed (B2B \& B2C) online tastings. B2B OWTs can be profitable in the long run, but show no immediate monetary benefit, whereas B2C OWTs directly generate profits as customers have to buy the tasting packages.

4.2.5 The future of OWTs. As indicated in Section 4.2.1, OWTs were organised and hosted primarily due to the Covid-19 pandemic. They served to compensate losses in direct sales and to create a new marketing platform. The pandemic is not over yet; nevertheless, the question of whether OWTs will continue to play an important role when the strong restrictions are over remains unanswered. We therefore asked both groups - wineries with and without OWTs - about their future activities. Wineries with experience in the field of OWTs seem to be very satisfied with the use and outcomes of this online tool. Accordingly, $64 \%$ stated that they want to continue offering OWTs, and another 34\% answered this question with a maybe. Only $3 \%$ do not plan to continue offering this type of wine tasting in the future. Given that wineries only have one year of experience with this online tool, this result speaks for the suitability and success of OWTs, as well as their right to exist.

When comparing the country of origin, the results show that Germany and the USA differ considerably from the remaining countries, with higher shares of respondents that want to continue offering OWTs. In terms of company size, no significant differences could be determined. This means that OWTs have been established in a record time of 12 months around the world.

Of those wineries that have not hosted OWTs, $13 \%$ want to start offering OWTs in the future, while $67 \%$ are considering this option. A mere $20 \%$ report not wanting to use this new online tool. Interestingly, no significant differences could be detected by country or the size of the company.

Based on these results, we assume that OWTs will continue to be offered after the Covid-19 crisis. This is in line with the previous study by Krupp (2020), who described a decreasing supply of OWTs after the first lockdown when shops and also wineries were allowed to open their doors again.

\section{Conclusion}

The findings with regard to the share of wineries offering OWTs (RQ1) indicate that only a certain number of wineries decided to apply this new virtual approach to tasting activities. The analysis of the reasons pro OWTs (RQ2) shows that virtual tastings can be seen as an "all-in-one" tool, which has a multifunctional role in terms of offering a marketing platform, taking the place of cancelled or postponed wine tastings and focusing on loyalty, as well as the acquisition of new customers. The results also provide evidence that OWTs are a brandnew instrument in the tool kit of wine companies. OWTs targeting business customers are on average shorter, with fewer participants, and they mainly serve to replace cancelled wine fairs (RQ3).

One of the most important findings in terms of understanding OWTs is the profitability of these events (RQ4). As recognised in previous studies, tasting rooms are the most profitable outlets of a winery, owing to the high margins associated with sales (Bruwer et al., 2011). We have shown that conducting OWTs is a good stroke of business and can compensate, at least partly, the sales losses resulting from the Covid-19 lockdown. However, we have to separate $\mathrm{B} 2 \mathrm{~B}$ OWTs and those that are aimed at B2C customers. B2B OWTs have a rather longer-term effect on profitability and that they are likely to have been hosted to bridge the gap that originated from a lack of $\mathrm{B} 2 \mathrm{~B}$ events and fairs where producers meet importers, exporters and retailers.

Regarding future activities, we can conclude that OWTs are here to stay (RQ5). More than half of the wineries with OWTs are willing to continue running them in the future, and about 
BFJ

123,13

612

two-third of wineries that have not conducted OWTs so far are considering offering virtual tastings.

The main reasons and objectives for conducting OWTs have shown that the pandemic's negative effects were a driver of innovation towards digitalisation. Wineries were stimulated to think out of the box and use new strategies to keep in touch with their clients and sell them wine. These results and the steadily rising numbers of OWTs indicate that these virtual tastings will not lose their relevance anytime soon. This statement is supported by Lehnardt (2020).

\subsection{Scholarly and managerial implications}

As one of the main scientific implications of this paper, we emphasise the need to analyse this new online tool. This study aims to fill the gap of missing scientific literature in wine tourism activities during the Covid-19 pandemic.

Another scientific implication concerns the international context of the survey. With the help of this global survey, cross-national similarities and differences between seven countries and the rest of the world have been analysed in terms of using OWTs.

In regard to managerial implications, OWTs seem to be a simple tool that can be used to fill the gap left by physical wine tastings; however, they need a certain amount of investment and preparation. According to Urban (2020) and Kirschenmann (2020), planning OWTs involves some critical points that should be considered. First, a not very complex but appropriate video and audio technique is required. As the results of the qualitative survey show, at the beginning of the pandemic, several wineries used a simple laptop or tablet. Later on, more professional equipment was provided to guarantee a better quality. Wineries could consider whether it makes sense for them to utilise service providers for this or whether they should develop the technical expertise themselves. As part of the technical issue, the software for hosting the event should also be selected. For contacting potential participants, a wellmaintained customer relationship management (CRM) system could be of great importance as otherwise wineries will have to practise "cold calls" to attract unknown customers. Generating tasting content, the appropriate presentation of the winery, knowledge transfer and customer interaction during an OWT are very comparable to in offline settings, which indicates that the increased usage of OWTs will mitigate these issues.

Despite the challenges wineries are facing when hosting OWTs for the first time, advantageous cost implications appear. Both investments and advertising costs are low and do not pose any risk to wineries. This should be further encouragement to start utilising this tool. OWTs can help reduce the costs of samples in a B2C context, as clients purchase tasting sets without tasting beforehand, generating a turnover per tasting set that is comparable to the average spend of cellar door visitors. They also offer significant potential for reducing both travel expenses and working hours regarding interaction with professional clients. These versatile effects can offer different wineries outcomes best suited to their specific structures. Thus, wineries planning to utilise OWTs should define the positive effects they wish to achieve through their use and then employ them strategically to ensure they attain the desired economic benefits.

The new marketing opportunities offered by OWTs tap into the digitalisation megatrend, which has been accelerated by the pandemic. This constitutes another reason for wineries to seriously consider working with OWTs in the future. OWTs offer wineries with another digital opportunity to communicate with their clients in a personal way via digital platforms. Many of these platforms, such as Facebook, Instagram or YouTube, are amongst the most far-reaching social media websites and have enabled many companies to successfully build their brands and interact with their clients. OWTs have gained numbers of new private clients for wineries and have become a new product for most wineries. Clients are now able to book individual group tastings without needing to be physically present at the wineries. 
This significantly increases wineries' product offerings while adding a valuable new marketing opportunity that is also likely to contribute positively to wineries' incomes. They also provide the additional opportunity of purchasing afterwards as well as a high likelihood of generating positive word-of-mouth effects.

OWTs also support a green and sustainable solution for the future. Less travelling is a positive effect of online events; this modern form of wine tastings contributes to a better carbon footprint. Besides, the social aspect of sustainability is affected by supporting a better work-life balance of the winemakers. This is because the winemakers do not have to clean and wash up after the event.

\subsection{Limitations and further research}

One of the main limitations of this paper is the number of respondents from different countries. Due to the limited response rate, especially from New World countries such as Australia, New Zealand and Argentina, only 7 countries have been compared with each other - from these countries, at least 50 wineries filled in the questionnaire. The findings do not represent the entire total population of wineries, however, they allow the first insights and show a tendency in the selected seven countries. As a further limiting factor, the qualitative pre-study only focused on one country. Since the qualitative research only served the questionnaire development, we consciously decided on this one country, being well aware of the popularity and high number of OWTs in Germany.

Further substantiating the data would require following the progress of OWTs over a longer period while taking a closer look at more detailed parts of the topic. The use of quantitative research repeated during and after the pandemic would support the robustness of the results and quantify the findings of the qualitative study in the long term. Besides, further research should be conducted on other strategies in the wine industry to reduce losses or to survive the crisis caused by the Covid-19 pandemic.

\section{References}

Abrahamsson Lindeblad, P. (2012), "Organisational effects of virtual meetings: how can we gain from fewer handshakes? IIIEE Master Thesis IMEN41 20122", available at: http://lup.lub.lu.se/ student-papers/record/3125868 (accessed 8 January 2021).

Agnoli, L., Capitello, R. and Begalli, D. (2013). Factors influencing the decision-making process of the new wine consumers. 6th Annual Conference of the EuroMed Academy of Business, Estoril, Cascais, Portugal, 23-24 September 2013 Volume: Confronting contemporary business challenges through management innovation.

Alaimo, L.S., Fiore, M. and Galati, A. (2020), "How the covid-19 pandemic is changing online food shopping human behaviour in Italy", Sustainability, Vol. 20 No. 12, p. 9594.

Anderson, L. and Anderson, T. (2009), "Online professional development conferences: an effective, economical and eco-friendly option", Canadian Journal of Learning Technology, Vol. 35 No. 1, pp. 1-10, doi: 10.21432/T29015.

BBC (2020), "Coronavirus: a visual guide to the economic impact”, available at: https://www.bbc.com/ news/business-51706225.

Bresciani, S., Ferraris, A., Santoro, G. and Nilsen, H.R. (2016), "Wine sector: companies' performance and green economy as a means of societal marketing", Journal of Promotion Management, Vol. 22 No. 2, pp. 251-267.

Bruwer, J. (2002), "The importance and role of the winery cellar door in the Australian wine industry: some perspectives", The Australian New Zealand Grapegrower and Winemaker, Vol. 2002 No. 1, pp. 96-99.

Bruwer, J. and Lesschaeve, I. (2012), "Sources of information used by tourists travelling to visit Canadian winery tasting rooms", Tourism Planning and Development, Vol. 9 No. 3, pp. 269-289.
Online wine tastings during Covid-19 pandemic 
BFJ 123,13
Bruwer, J. and Reilly, M. (2006), "The power of word-of-mouth communication as an information source for winery cellar door visits”, Wine Industry Journal, Vol. 21 No. 3, pp. 43-51.

Bruwer, J., Saliba, A.J. and Miller, B. (2011), "Consumer behaviour and sensory preference differences: implications for wine product marketing", Journal of Consumer Marketing, Vol. 28 No. 1, pp. 5-18.

Bruwer, J., Coode, M., Saliba, A. and Herbst, F. (2013), "Wine tourism experience effects of the tasting room on consumer brand loyalty", Tourism Analysis, Vol. 18 No. 1, pp. 399-414, doi: 10.3727/ $108354213 X 13736372325957$.

Carmer, A., Velikova, N., Hertzman, J., Bergman, C., Wray, M. and Pippert, T.L. (2020), “An inquiry into the pedagogy of the sensory perception tasting component of wine courses in the time of COVID-19”, Wine Business Journal, Vol. 4 No. 2, pp. 96-115, doi: 10.26813/001c.22052.

Creswell, J.W., Plano Clark, V.L., Gutmann, M.L. and Hanson, W.E. (2003), "Advanced mixed methods research designs", in Tashakkori, A. and Teddlie, C. (Eds), Handbook of Mixed Methods in Social and Behavioral Research, Sage, Thousand Oaks, CA, pp. 209-240.

Cuellar, S.S. and Eyler, R.C. (2012), "Does higher tasting room traffic lead to increased sales?", Vineyard and Winery Management, May-June, pp. 74-78.

Cuellar, S., Eyler, R. and Fanti, R. (2015), "Experiential marketing and long-term sales", Journal of Travel and Tourism Marketing, Vol. 32 No. 5, pp. 534-553, doi: 10.1080/10548408.2014.918925.

Der Spiegel (2020), "Kreativ gegen Corona - Winzer stellen auf Online-Weinproben um”, available at: https://www.spiegel.de/wirtschaft/unternehmen/coronavirus-winzer-stellen-auf-onlineweinproben-um-a-2961fe09-0508-4289-a1ce-8f7cd63a23d0 (accessed 24 November 2020).

Destatis (Federal Statistical Office) (2020), Gesellschaftliche Auswirkungen, Statistiken und strukturelle Daten mit Bezug zu COVID-19, Mobilitätsveränderungen, Statistisches Bundesamt, available at: https://www.destatis.de/DE/Themen/Querschnitt/Corona/Gesellschaft/kontextinformationengesellschaft.html\#Mobi (accessed 12 January 2021).

Fabius, V., Kohli, S., Timelin, B. and Moulvad Veranen, S. (2020), Meet the Next-Normal Consumer, McKinsey \& Company, available at: https://www.mckinsey.com/business-functions/marketingand-sales/our-insights/meet-the-next-normal-consumer (accessed 12 December 2020).

Ferraris, A., Del Giudice, M., Grandhi, B. and Cillo, V. (2020), "Refining the relation between causerelated marketing and consumers purchase intentions: a cross-country analysis", International Marketing Review, Vol. 37 No. 4, pp. 651-669, doi: 10.1108/IMR-11-2018-0322.

Field, A. (2005), Discovering Statistics with SPSS, Sage Publications, London, United Kingdom.

Fischer, C. (2009), "Wine Tasting 2.0 - an increasing number of wineries are discovering the costsaving and networking benefits of online wine tasting”, Wine Business Monthly, Sep 2009 Issue, available at: https://www.winebusiness.com/wbm/?go $=$ getArticleSignIn\&dataId $=68646$ (accessed 12 November 2021).

Fountain, J., Fish, N. and Charters, S. (2008), "Making a connection: tasting rooms and brand loyalty", International Journal of Wine Business Research, Vol. 20 No. 1, pp. 8-21, doi: 10.1108/ 17511060810864589.

Friedman, H.H. and Amoo, T. (1999), "Rating the rating scale", The Journal of Marketing Management, Vol. 9 No. 3, pp. 114-123.

Galati, A., Tinervia, S., Tulone, A. and Crescimanno, M. (2018), "Drivers affecting the adoption and effectiveness of social media investments", International Journal of Wine Business Research, Vol. 31 No. 2, pp. 260-278.

Galati, A., Sakka, G., Crescimanno, M., Tulone, A. and Fiore, M. (2019), "What is the role of social media in several overtones of CSR communication? The case of the wine industry in the Southern Italian regions", British Food Journal, Vol. 121 No. 4, pp. 856-872.

Garibaldi, R. (2020), "The impact of COVID-19 on wine tourism. At 20UNWTO-OIV webinar: innovating in wine tourism in the contest of COVID-19", September 20, 2020, available at: https:/www.unwto. org/events/innovating-in-wine-tourism-in-the-context-of-covid-19 (accessed 8 February 2021). 
Gilbert, J. (2020), "Virtual happy hour leads on-trade support initiatives”, Harpers.co.uk, available at: https://harpers.co.uk/news/fullstory.php/aid/26792/Virtual_Happy_Hour_leads_on-trade_ support_initiatives.html (accessed 15 March 2021).

Gill, D., Byslma, B. and Ouschan, R. (2007), "Customer perceived value in a cellar door visit: the impact on behavioural intentions", International Journal of Wine Business Research, Vol. 19 No. 4, pp. 257-275, doi: 10.1108/17511060710837418.

Harpers (2020), “Company news: adapting to a new 'norm', Harpers”, March 27, 2020, available at: https://harpers.co.uk/news/fullstory.php/aid/26847/Company_news:_adapting_to_a_new_ 91norm_92_html (accessed 12 March 2021).

Henry, A. and Shellenbarger, T. (2020), Choosing a Videoconferencing Platform, Nurse Author \& Editor, November 5, 2020, available at: https:/naepub.com/collaboration/2020-30-4-3/ (accessed 12 January 2021).

Ho, F. and Gallagher, M. (2005), "The impact of wine tasting on wine purchases: evidence from Napa, California", International Journal of Wine Marketing, Vol. 17 No. 1, pp. 44-53, doi: 10.1108/ eb008782 (accessed 8 January 2021).

Janney, L.A. (2012), Factors that Create a Positive Tasting Room Experience for the Current Millennial Generation, Bachelor of Science Thesis, Faculty of the Agribusiness Department California, Polytechnic State University.

Kirschenmann, E. (2020), Virtual wine tastings become key consumer engagement tool, wine business monthly, Mai 2020, pp. 64-92, available at: https://www.winebusiness.com/wbm/? go $=$ getArticleSignIn\&dataId $=229505$ (accessed 8 January 2021).

Krippendorff, K. (2004), Content Analysis: An Introduction to its Methodology, Sage Publications, CA. Krupp, N. (2020), "Weinprobe - online ein Hype?”, Das Deutsche Weinmagazin, Vol. 2020 No. 14, pp. 29-32.

Kuntz, J., Kavalieratos, D., Esper, G.J., Ogbu, N., Mitchell, J., Ellis, C.M. and Quest, T. (2020), "Feasibility and acceptability of inpatient palliative care E-family meetings during COVID-19 pandemic", Journal of Pain and Symptom Management, Vol. 60 No. 3, pp. 28-32, doi: 10.1016/j. jpainsymman.2020.06.001.

Lehnardt, E. (2020), "Neue Corona Regeln - Einschränkungen bei Feiern und Corona-Ampel für Deutschland? Das plant Merkel für den Herbst”, Südwest Press, available at: https://www.swp. de/politik/inland/corona-regeln-neu-deutschland-bw-bayern-merkel-will-obergrenze-fuer-feiernund-alkohol-coronavirus-fallzahlen-51889760.html (accessed 12 March 2021).

Lockshin, L. and Knott, D. (2009), "Boozing or branding? Measuring the effects of free wine tastings at wine shops", International Journal of Wine Business Research, Vol. 21 No. 4, doi: 10.1108/ 17511060911004897.

Lönarz, R. (2021), Wine-Event "Riesling Worldwide", Hochschule Geisenheim, available at: https:// www.hs-geisenheim.de/medienprojekte/wine-event-2001/. accessed March 10, 2021.

Loose, S. and Nelgen, S. (2021), “Corona-Folgen”, Der Detusche Weinbau, Vol. 21 No. 3, pp. 18-21.

McMillan, R. (2019), State of the Wine Industry Report 2019. Silicon Valley Bank, Wine Division, 2019, St Helena, USA, available at: https:/www.svb.com/globalassets/library/images/content/trends_ and_insights/reports/wine_report/svb-2019-wine-report (accessed 8 February 2021).

Meininger Sommelier (2020), "Virtuelle Weintour, sommelier”, April 6, 2020, available at: https://www. meininger.de/de/meiningers-sommelier/news/virtuelle-weintour (accessed 10 March 2021).

Meininger's Weinwelt (2020), "Live-Wein-Tastings über cheerswith.me. Weinwelt", April 2, 2020, available at: $\mathrm{https} / / \mathrm{www}$.meininger.de/de/meiningers-weinwelt/news/live-wein-tastings-uebercheerswith-me (accessed 12 March 2021).

Mitchell, R. and Hall, C. (2004), "The post-visit consumer behaviour of New Zealand winery visitors", Journal of Wine Research, Vol. 15 No. 1, pp. 39-49, doi: 10.1080/0957126042000300317.

Mueller, S., Remaud, H. and Chabin, Y. (2011), "How strong and generalisable is the Generation Y effect? A cross-cultural study for wine”, International Journal of Wine Business and Research, Vol. 23 No. 2, pp. 124-144.
Online wine tastings during Covid-19 pandemic

615 
BFJ 123,13

Nowak, L. and Newton, S. (2006), "Using the tasting room experience to create loyal customers. International", Journal of Wine Marketing, Vol. 18 No. 3, pp. 157-165, doi: 10.1108/ 09547540610704738.

OECD (2020), "Tourism policy responses to the coronavirus (COVID-19) 2020", available at: https:// www.oecd.org/coronavirus/policy-responses/tourism-policy-responses-to-the-coronavirus-covid19-6466aa20/ (accessed 12 March 2021).

Riley, L. (2020), "Hallgarten launches weekly virtual tasting series. Harpers Magazine", June 2020, available at: https:/harpers.co.uk/news/fullstory.php/aid/27267/Hallgarten_launches_weekly_ virtual_tasting_series.html (accessed 14 January 2021).

Saayman, M. and van der Merwe, A. (2015), "Factors determining visitors' memorable wine-tasting experience at wineries”, Anatolia, Vol. 26 No. 3, pp. 372-383, doi: 10.1080/13032917.2014.968793.

Saini, S., Bansal, A. and Sadhana, R.K. (2020), "A study on the impact of Corona virus (COVID-19) on the global food industry", International Journal in Management and Social Science, Vol. 08 No. 06 , pp. 60-66.

Santos, V., Ramos, P., Sousa, B. and Valeri, M. (2021), "Towards a framework for the global wine tourism system", Journal of Organizational Change Management, Vol. ahead-of-print No. aheadof-print, doi: 10.1108/JOCM-11-2020-0362.

Serhan, D. (2020), “Transitioning from face-to-face to remote learning: students' attitudes and perceptions of using Zoom during COVID-19 pandemic", International Journal of Technology in Education and Science, Vol. 4 No. 4, pp. 335-342.

Shapiro, M. and Gómez, M. (2014), "Customer satisfaction and sales performance in wine tasting rooms", International Journal of Wine Business Research, Vol. 26 No. 1, pp. 45-60, doi: 10.1108/ IJWBR-09-2012-0026.

Siagian, H., Putera, G. and Burlakovs, J. (2020), "The effect of product knowledge on salesperson performance with the moderating role of attitude", SHS Web of Conferences, Vol. 76, doi: 10. 1051/shsconf/20207601011.

Smyczek, S., Festa, G., Rossi, M. and Monge, F. (2020), "Economic sustainability of wine tourism services and direct sales performance - emergent profiles from Italy", British Food Journal, Vol. 122 No. 5, pp. 1519-1529, doi: 10.1108/BFJ-08-2019-0651.

Suckling, J. (2020), "Zoon tasting Bordeaux 2019 en primeur with Château Croix de Labrie”, April 15 2020, available at: https://www.jamessuckling.com/videos/video-zoom-tasting-2019-en-primeurchateau-croix-de-labrie/ (accessed 5 February 2021).

Szolnoki, G. (2018), Wine Consumer Report - Germany, Geisenheim University, Professorship for Market Research, available at: https://www.hsgeisenheim.de/forschung/institute/wein-undgetraenkewirtschaft/professur-fuer-marktforschung/bildung-praxis/\#collapse24361 (accessed 15 March 2021).

Szolnoki, G., Taits, D., Nagel, M. and Fortunato, A. (2014), Using social media in the wine business an exploratory study from Germany, International Journal of Wine Business Research, Vol. 26 No. 2, pp. 80-96, doi: 10.1108/IJWBR-09-2013-0031.

Szolnoki, G., Dolan, R., Forbes, S., Thach, L. and Goodman, S. (2018), "Using social media for consumer interaction: an international comparison of winery adoption and activity", Wine Economics and Policy, Vol. 7 No. 2, pp. 109-119, doi: 10.1016/j.wep.2018.07.001.

Tafel, M. and Szolnoki, G. (2020), "Estimating the economic impact of tourism in German wine regions", International Journal of Tourism Research, Vol. 2020 No. 1, pp. 1-12, doi: 10.1002/jtr.2380.

Thach, L. and Velikova, N. (2020), New Study Explores Motivations and Behaviors of US Wine Consumers before and during COVID-19 Lockdown, Winebusiness.com, June 11, 2020, available at: https:// www.winebusiness.com/news/?go = getArticle\&dataId=232120 (accessed 10 January 2021).

UNCTAD (2020), "COVID-19 has changed online shopping forever, survey shows", United Nations Conference on Trade and Development, October 8, 2020, available at: https://unctad.org/news/ covid-19-has-changed-online-shopping-forever-survey-shows (accessed 12 January 2021). 
Urban, J. (2020), "Virtuelle Weinproben, Tipps \& Tricks für die Praxis", Das deutsche Weinmagazin, Vol. 2020 No. 14, pp. 24-27.

Velikova, Natalia and Dodd, Tim (2009), "There is no such thing as a free wine tasting: the effect of a tasting fee on obligation to buy", Journal of Travel \& Tourism Marketing, Vol. 26 No. 8, pp. 806-819, doi: 10.1080/10548400903356228.

Veseth, M. (2017), Economic Impact of California Wine Country Wildfires: Preliminary Analysis, The Wine Economist, October 17, 2020, available at: https://wineeconomist.com/2017/10/17/ wildfires/ (accessed 10 February 2021).

Vrontis, D., Basile, G., Tani, M. and Thrassou, A. (2020), "Culinary attributes and technological utilisation as drivers of place authenticity and branding: the case of Vascitour, Naples", Journal of Place Management and Development, Vol. 14 No. 1, pp. 5-18.

WeinPlus (2021), "Internet wine tasting", available at: https://glossary.wein.plus/internet-wine-tasting (accessed 12 June 2021).

Wen, H. and Leung, X.Y. (2021), "Virtual wine tours and wine tasting: the influence of offline and online embodiment integration on wine purchase decisions", Tourism Management, Vol. 83 No. 1, p. 104250, doi: 10.1016/j.tourman.2020.104250.

Wine Intelligence (2020a), Germany Covid-19 Impact Report Issue \#1, Wine Intelligence, London, 2020.

Wine Intelligence (2020b), Wine Consumer Trends in the COVID-19 Era Issue \#2, Wine Intelligence, London, 2020.

World Bank (2020), "COVID-19 to plunge global economy into worst recession since world war II", available at: https://www.worldbank.org/en/news/press-release/2020/06/08/covid-19-to-plungeglobal-economy-into-worst-recession-since-world-warii\#: :text=According $\% 20$ to $\% 20$ World $\%$ 20Bank $\% 20$ forecasts, shrink $\% 20$ by $\% 205.2 \% 25 \% 20$ this $\% 20$ year.\&text $=$ That $\% 20$ would $\%$ 20represent $\% 20$ the $\%$ 20deepest,June $\% 202020 \%$ 20Global $\% 20$ Economic $\% 20$ Prospects (accessed 12 January 2021).

\section{Further reading}

DWI (2020), Weinabsatz im zweiten Quartal gestiegen, Deutsches Weininstitut, Bodenheim, available at: https://www.deutscheweine.de/presse/pressemeldungen/details/news/detail/News/ weinabsatz-im-zweiten-quartal-gestiegen/ (accessed 10 February 2021).

Penn, C. (2019), "Tasting room survey report-visitor counts increase in emerging regions, decline in Napa, Wine Business Monthly", issue July 2019, available at: https:/www.winebusiness.com/ $\mathrm{wbm} /$ ?go $=$ getArticleSignIn\&dataId $=216038$ (accessed 24 November 2020).

\section{Corresponding author}

Gergely Szolnoki can be contacted at: Gergely.Szolnoki@hs-gm.de

For instructions on how to order reprints of this article, please visit our website:

www.emeraldgrouppublishing.com/licensing/reprints.htm

Or contact us for further details: permissions@emeraldinsight.com
Online wine tastings during Covid-19 pandemic 